\title{
Contributions to the knowledge of the flora of the Balearic Islands: Notes on the genus Potamogeton and Stuckenia (Potamogetonaceae)
}

\section{Llorenç Sáez}

Universitat Autònoma de Barcelona. Unitat de Botànica

Facultat de Biociències. 08193 Bellaterra

llorens.saez@uab.cat

\section{Nèstor Torres}

Apartat 64. 07800 Eivissa

nestor.torres@telefonica.net

\section{Llorenç Gil}

Universitat de les Illes Balears. Laboratori de Botànica

Edifici Guillem Colom, Ctra. Valldemossa, km 7,5. 07122 Palma de Mallorca

lorenzo.gil@uib.es

Pere Aymerich

C/ Barcelona 29, 08600 Berga

pere_aymerich@yahoo.es

\section{Pere Fraga}

Institut Menorquí d'Estudis. Secció de Ciències Naturals

Camí des Castell 28. 07702 Maó

pere.fraga@gmail.com

\begin{abstract}
An investigation on the genus Potamogeton and Stuckenia (Potamogetonaceae) in the Balearic Islands is presented. For each of the species we provide comments on its morphology, as well as data on its ecology and distribution. The presence of Potamogeton lucens and $P$. natans in the Balearic Islands is excluded, whereas the occurrence in the Balearic archipelago of the European and African species Potamogeton schweinfurthii is newly recorded.
\end{abstract}

Keywords: aquatic plants; variability; distribution range; Mediterranean region; taxonomy.

Resum. Contribucions al coneixement de la flora de les Illes Balears: Notes en els gèneres Potamogeton $i$ Stuckenia (Potamogetonaceae) 
Es presenta una revisió dels gèneres Potamogeton i Stuckenia (Potamogetonaceae) a les Illes Balears. Per a cada espècie acceptada s'aporten dades i comentaris sobre la morfologia, l'ecologia i la distribució. S'exclou la presència de Potamogeton lucens i de P. natans a les Illes Balears, mentre que s'indica per primera vegada la presència en aquest arxipèlag de Potamogeton schweinfurthii, una espècie de distribució europea i africana.

Paraules clau: plantes aquàtiques; variabilitat; distribució; regió mediterrània; taxonomia.

\section{Introduction}

Although knowledge of the Balearic Islands flora can be regarded as relatively good, there are still some poorly known genera and families. Among these, we find the genera Potamogeton L. and Stuckenia Borner (Potamogetonaceae), both of which include aquatic plants. Although the genus Stuckenia has usually been included within Potamogeton, recent molecular and morphologic studies indicate that Potamogeton in the broad sense actually comprises two separate lineages. Those lineages are currently recognized at the generic level: Potamogeton in the strict sense, and Stuckenia, which is characterized mainly by the presence of long leaf sheaths, characteristic leaf and peduncle anatomy, and a higher ploidy level than in Potamogeton s. str. (Kaplan, 2008). Both genera are important to address a variety of biological phenomena, including the topics of phenotypic plasticity (Kaplan, 2002), different pollination systems (Zhang et al., 2010), and the role of hydrodynamic processes (Koch et al., 2010) and biotic mechanisms (Brochet et al., 2010) in the dispersal of these macrophytes.

The high phenotypic plasticity of Potamogeton and Stuckenia, which is even appreciable for a single clone (Kaplan, 2002), together with its adaptation to permanent or temporal habitats and traditions in floristic publications, have caused certain confusion for the correct identification of these genera in the Balearic archipelago. In this paper we provide detailed data to establish the identity and distribution of the species of these genera that exist in the Balearic Islands.

\section{Material and methods}

We have compiled a bibliography of the genus Potamogeton and Stuckenia in the Balearic Islands in order to update the catalogue of taxa listed in the archipelago. We have prioritized the search for bibliographic information sources that provide specific records, since most compilations or appointments simply reproduce previous catalogues. In addition, we have reviewed, where possible, all herbarium materials of both genera, especially in the case of rare taxa, or those of questionable presence in the archipelago. Specimens deposited in the following herbaria were reviewed: BC, BCN, COI-Willk., HJBS, herb. Universitat Illes Balears, herb. Generale Minoricae, MA, Herb. N. Torres and MPU-Knoche. When voucher specimens could not be relocated, field surveys were performed to confirm their presence. Identifications of broad-leaved pondweed occurring in the Balearic Islands were made according to morphological characters and diagnoses given by 
Kaplan (2005), Wiegleb and Kaplan (1998), García Murillo (2010), and Lastrucci et al. (2010). Finally, we provide data from field surveys conducted by the authors. For each of the species, data on their distribution in the archipelago, abundance, ecology, altitude range, known locations and other supplementary data such as morphological variability, validity of some dubious references, etc. are provided.

\section{Results}

Six species have been accepted in the present revision of the pondweed flora of the Balearic Islands. Two species (Potamogeton lucens and P. natans) should be excluded. These data are summarized in Table 1, where the presence of the accepted species per island is also indicated.

Table 1. Species of Potamogeton and Stuckenia currently accepted for the Balearic Islands. +: confirmed species; $(+)$ : presence of unconfirmed in recent times; ?: uncertain presence

\begin{tabular}{|c|c|c|c|c|c|}
\hline \multirow[b]{2}{*}{ Species } & \multicolumn{3}{|c|}{$\begin{array}{c}\text { Eastern } \\
\text { Balearic Islands }\end{array}$} & \multicolumn{2}{|c|}{$\begin{array}{c}\text { Western } \\
\text { Balearic Islands }\end{array}$} \\
\hline & Mallorca & Menorca & Cabrera & Eivissa & Formentera \\
\hline Potamogeton coloratus & + & + & & + & \\
\hline Potamogeton crispus & + & + & & & \\
\hline Potamogeton nodosus & + & & & & \\
\hline Potamogeton pusillus & + & + & & & \\
\hline Potamogeton schweinfurthii & & + & & + & \\
\hline Stuckenia pectinata & + & + & $?$ & $(+)$ & $(+)$ \\
\hline
\end{tabular}

The following data are provided for Potamogeton and Stuckenia species whose presence has been confirmed in the Balearic Islands, or those that have been reported in the most relevant literature.

\section{Confirmed species}

\section{Potamogeton coloratus Hornem}

In the Balearic Islands, $P$. coloratus has been confused with three species of the genus: $P$. nodosus, $P$. lucens, and $P$. natans. The last two should be excluded from the flora of the Balearic archipelago (see the comments below regarding these two species).

Potamogeton coloratus is one of the most common species of pondweeds in the Balearic archipelago (Fig. 2). It has been found in a rather wide variety of aquatic habitats, including streams, ponds, and ditches. Their populations are found from sea level to about $700 \mathrm{~m}$. The examined specimens of P. coloratus have a wide morphological variability range. We found that the number of leaf veins can be lower than stated in recent revisions of the genus. Leaves with only 7 nerves were observed (Fig. 1), which is below the minimum indicated by Ka- 

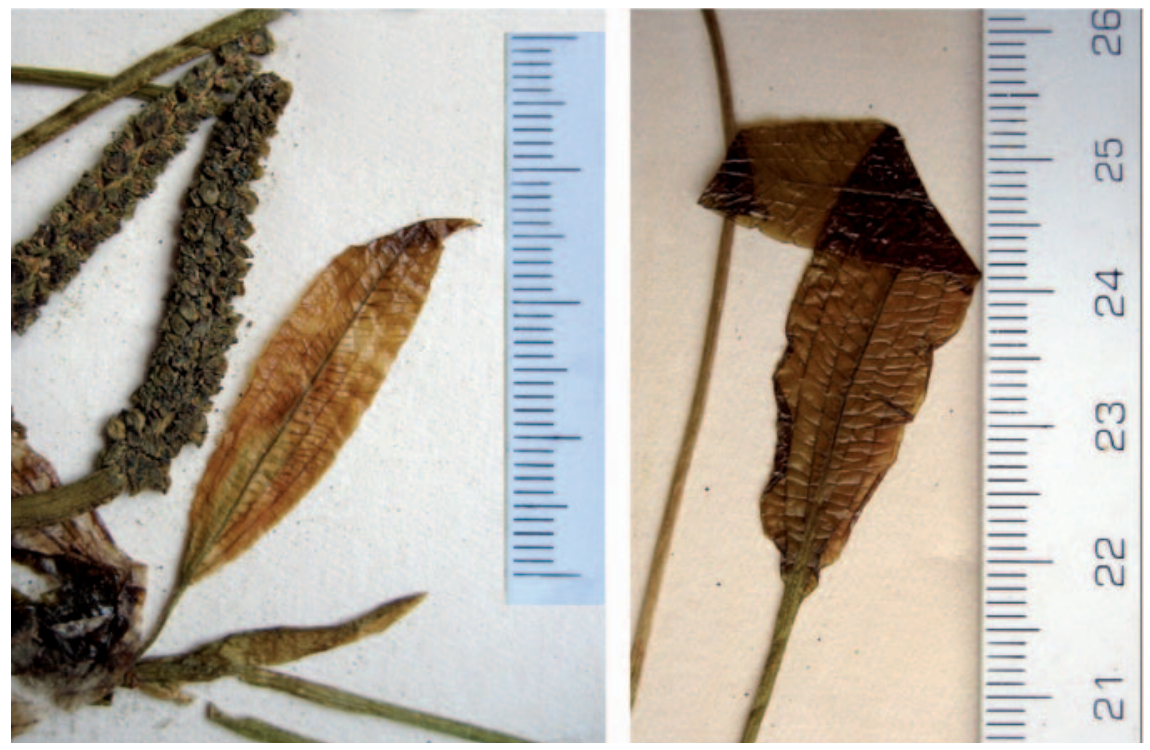

Figure 1. Leaves of herbarium specimen labelled as Potamogeton lucens from Gorg Blau, Mallorca (HJBS 124). This herbarium specimen should be referred to Potamogeton coloratus.

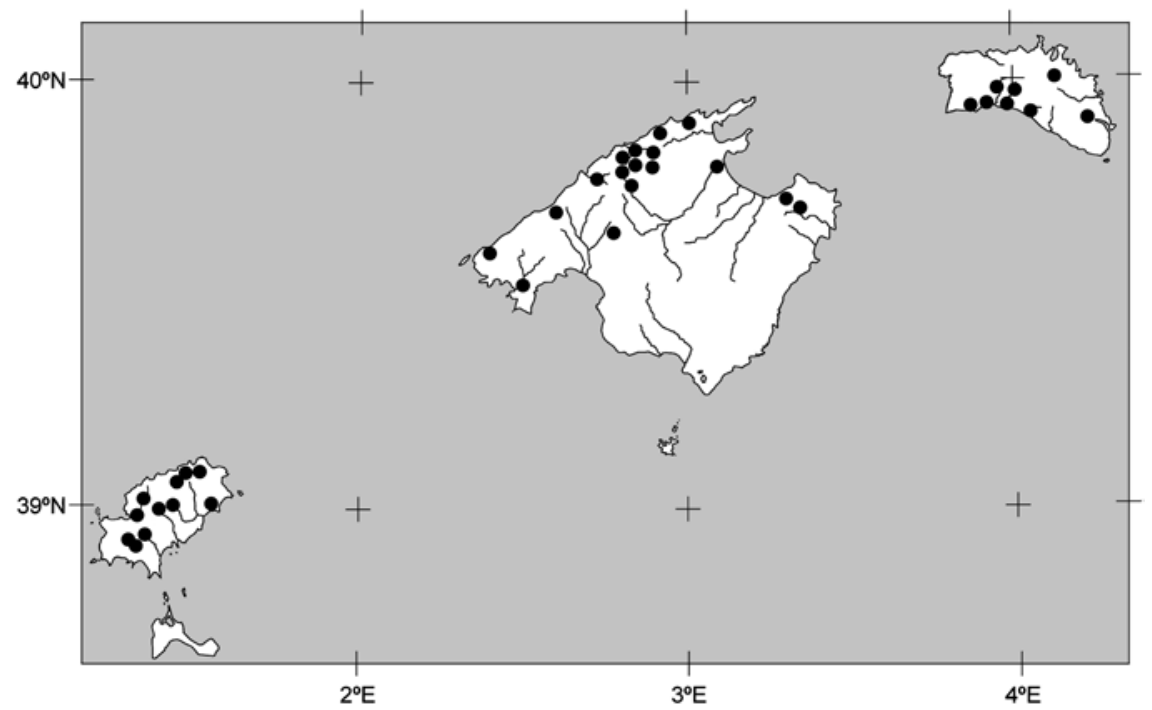

Figure 2. Distribution of Potamogeton coloratus in the Balearic Islands. 
plan (2005) [9-17 nerves] and García Murillo (2010) [13-17 nerves]. In our opinion, this character is somewhat variable. In several populations from the north-eastern Iberian Peninsula, specimens of $P$. coloratus with 7-nerved leaves are not uncommon, mainly in the upper sections of the stems, where leaves are relatively young and small.

\section{References and revised specimens}

MallorCA: Lluch, en la fuente de Son Amer, 4-IV-1948, P. Palau (MA 37965); Font Freda (Lluc), 7-V-1950, P. Palau 282 (BC 113489, BCN 3296: MA 348161, MA 160812); Lluc, V-1950, P. Palau (BC 113372); Santa Ponsa, Potamion, 29VI-1954, O. Bolòs \& P. Palau (BC 135907); Turixant de Baix, DE8507, VII1971, A. Llorens (LLGLGV002576); Son Amer (Lluc), DE9007, VII-1971, A. Llorens (LLGLGV002574); Gorg Blau, DE80A, XI-1976, L. Llorens (LLGLGV002578); Artà, Ermita de Betlem, réservoir d'eau à la fontaine de l'Ermitage, 14-IV-1977, J. Duvigneaud 77E141 (MA 285266, MA 334895); estanque cerca de Santa María, 19-II-1978, s.r. (UIB 10995); Torrent de Pareis, Majorque, 17-VII-1978, P. Sotiaux (MA 731391); S'Albufera, lloc inundat, 21VII-1979, s.r. (UIB 10996); Torrente Pto. de Valldemossa, 21-II-1983, C. Magraner Pizà, 21-II-1983 (UIB 10998); Torrent d'Almadrà, DE8302, 550 m, 3-IX-1985, G. Bibiloni 0225 (HJBS 1760, sub Potamogeton sp.); Pollensa, Ternelles, 31SDE91, 22-II-1987, J. Vicens (BCN 29277); Artà, sa Bassa d'Oli, 7-XII-1987, J.A. Rosselló 87-358 (HJBS 1759, sub Potamogeton sp.); Almadrà, 28-XI-1988, M. Mayol et al. (UIB 10991); Racó des Ratjolí, Andratx, 31SDD4885, 50 m, torrent, 28-XII-2000, L.G. Valle \& L. Sáez LS-5498 (L. Sáez herb. pers.); Prat d'en Josafat (Lluc), 26-VI-2001, J. Rita \& X. Cardona (UIB 16079); Torrent des Gorg Blau-Sa Fosca, 18-IV-2003, L. Guàrdia Valle \& L. Sáez; Torrent de Mortitx, 28-V-2003, L. Guàrdia Valle \& L. Sáez; Jardí Botànic de Sóller, 24-V2004, JR (UIB 16525); Lluc, s.d., G. Alomar (HJBS 1762, sub P. natans). MENORCA: Barranc d'Algendar, XII-1976, J. Rita (BC 621433); Son Bou (Alaior, Menorca), 11-VI-1977, J. Muntaner \& A. de Juan (BC 645232, sub P. pusillus L.); Sa Marjal Vell, Prat de Bellavista, 31SEE7620, 21-VII-1998, P. Fraga; Son Pruna, Barranc d'Algendar, 31SEE8225, 13-VIII-1996, P. Fraga; Sant Joan de Carbonell, 31SEE9628, 14-VII-2005, P. Fraga; Macarella, 31SEE8021, 20-VII1997, P. Fraga; Son Fideu, barranc d'Albranca, 31SEE8723, 15-VIII-1996, P. Fraga; Son Boter, barranc de Sa Vall, 31SEE9019, 12-VI-1994, P. Fraga; Barranc de Sant Joan, 31SFE0716, 20-VII-2007, P. Fraga; Trebalúger Nou, barranc de Trebalúger, 31SEE8421, 10-VII-1996, P. Fraga; Son Benet, barranc de Sa Vall, 31SEE9019, 15-VIII-2008, P. Fraga. EIvissa: S'Argamassa, Santa Eulària, Eivissa, 3-VI-1918, Gros (BC 630194); Safareig de Santa Gertrudis, 31-V-1950, R. Margalef (BC 111026, sub P. siculus Tin.?); Sant Antoni, aigües salobroses, 31-V-1950, R. Margalef (BC 111027); Sant Joan, Font, CD72, VI-1984, s.r. (UIB 15508); Torrent de ses Fonts, CD50A, 24-V-1986, s.r. (UIB10997); Sant Joan de Labritja, bassa torrent de Xarraca, 31SCD7028, 6-VII-1986, N. Torres (Herb. Nèstor Torres); torrent de Sa Llevanera, CD6116, 27-X-1986, s.r., (UIB10999); Sant Josep de sa Talaia: bassa font Paredada, puig Gros, Sant Jordi 31SCD5609, 
19-VI-1991, N. Torres (Herb. Nèstor Torres); Sant Antoni de Portmany: bassa prop es Broll de Buscastell 31SCD5820, 4-IV-1993, N. Torres (Herb. Nèstor Torres); Safareig al torrent des Buscastell (creuer amb la carretera Santa Agnès a Sant Antoni), CD5718, 6-VI-2000 L. Gil \& L. Llorens (LLGLGV002575); ibídem 9-XI-2002; Sant Joan de Labritja: bassa torrent port de Sant Miquel 31SCD6425, 24-IV-1999, N. Torres (Herb. Nèstor Torres); Sant Joan de Labritja: torrent font d'en Carreró, Benirràs, 31SCD6625, 1-IV-2006, N. Torres (Herb. Nèstor Torres); Sant Josep de sa Talaia: safareig vora torrent des Horts, 31SCD5307, 17-VIII-2002, N. Torres (Herb. Nèstor Torres); Sant Josep de sa Talaia: dins font des Verger, Sant Josep 31SCD5208, 1-XI-2002, N. Torres (Herb. Nèstor Torres); Sant Antoni de Portmany: safareig vora es pou des Escarabats, Buscastell, 31SCD5718, 10-V-2003, N. Torres (Herb. Nèstor Torres); Sant Joan de Labritja: bassa de la font d'en Mates, Benirràs, Sant Miquel; 31SCD6626, 31V-2003, N. Torres (Herb. Nèstor Torres).

\section{Potamogeton crispus L.}

This species, which is native to Europe, Africa, Australia, and Asia, is found in northern Mallorca and southern Menorca (Fig. 3). It grows in streams and canals, usually in water depths of at least $0.5 \mathrm{~m}$. In Mallorca, $P$. crispus is known from only one locality (S'Albufera d'Alcúdia), where it is abundant (Martínez Taberner, 1986), since it spreads mostly by means of vegetative reproduction, and can form dense mats of vegetation on the water surface. In Menorca it occupies areas along the Barranc d'Algendar, Barranc de Trebalúger and Barranc de Sa Vall.

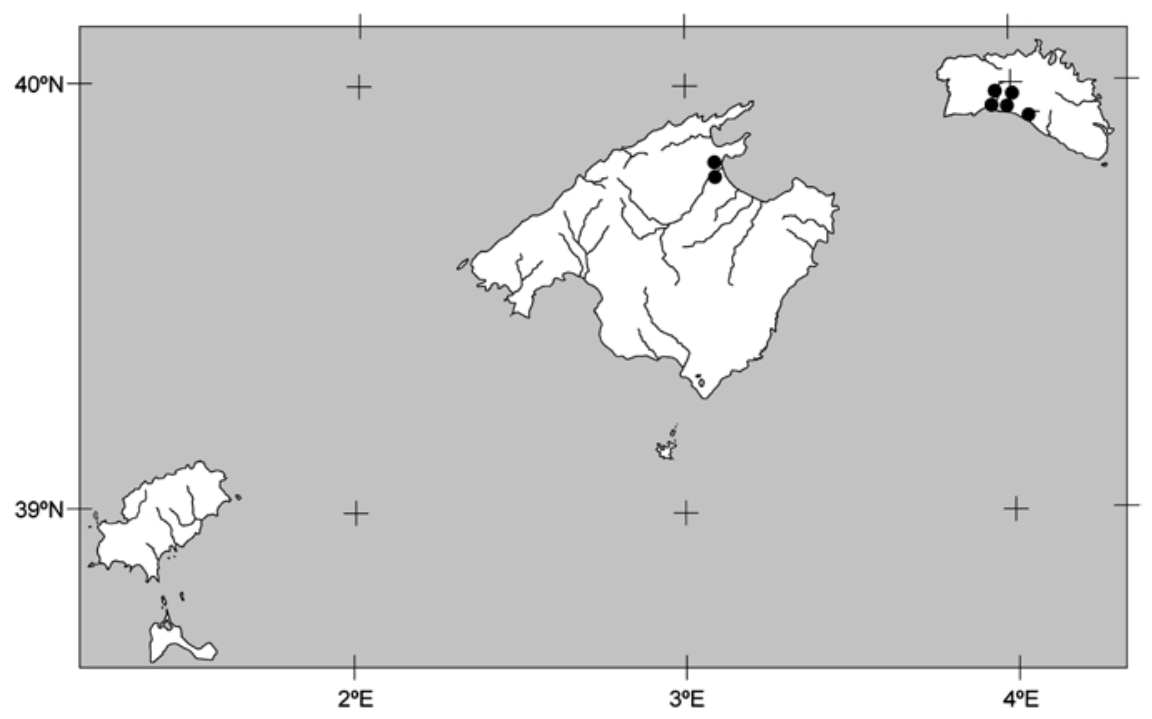

Figure 3. Distribution of Potamogeton crispus in the Balearic Islands. 
Most of the studied specimens matched the typical morphology of the species, with relatively broad leaves (7-14 mm wide) and distinctly undulated margin, usually more or less denticulate, but with some variability. Some specimens from southern Menorca (UIB 14924) have remarkably narrow leaves [3-6(7) mm wide] linear-oblong in shape (ratio length:width 6.5 to 12 ), with the entire margin weakly denticulate. However, these specimens fall within the variability range of the species (García Murillo, 2010: 78).

\section{References and revised specimens}

Mallorca: Font de Son Sant Joan, Muro, IV-1971, Bonafè (HJBS- Bonafè-0113, 0115); Albufera d'Alcúdia, canal dels Anglesos, 22-V-1971, Bonafè (HJBSBonafè-0114); Albufera, 11-IV-2002, M.A. Conesa \& Cardona (UIB 16185, 15789). Menorca: Barranc d'Algendar, 11-IV-2001, X. Cardona, E. Moragues \& J. Rita (UIB 14924); Es Molí de Dalt, barranc d'Algendar , 31SEE8225, 13VIII-1996, P. Fraga; Sa Canaleta, barranc d'Albranca, 31SEE8623, 15-VIII-1996, P. Fraga; Sa Vall, barranc de Sa Vall, 31SEE9020, 12-VI-1994, P. Fraga; Sa Dragonera, barranc d'Algendar, 31SEE8224, 15-VII-2013, P. Fraga, Son Fonoll, barranc d'Algendar, 31SEE8223, 23-VI-2004, P. Fraga; Son Mestres de Baix, Barranc d'Algendar, 31SEE8225, 23-VI-2004, P. Fraga; So n'Olivar, barranc de Trebalúger, 31SEE8521, 10-VII-2002, P. Fraga; Trebalúger Nou, Barranc de Trebalúger, 31SEE8421, 10-VII-1996, P. Fraga.

\section{Potamogeton nodosus Poir \\ -Potamogeton fluitans auct., non Roth}

This is an extremely rare species in the Balearic Islands, which is restricted to northern Mallorca (S'Albufera) (Llorens, 1972; Bonafè, 1977; Martínez Taberner, 1986) (Fig. 4). Early reports from Menorca (Rodríguez, 1874; 1904, sub $P$. fluitans) and eastern Mallorca (Canyamel) (Llorens, 1972, sub P. fluitans) have not been confirmed. The sole Minorcan specimen labelled as $P$. nodosus that we were able to study [Ual de Santa Catalina (Mahon), aguas corrientes, 1-III-1872, J.J. Rodriguez (COI-Willk., sub Potamogeton natans L. var. fluitans)] corresponds to $P$. coloratus. In the case of the locality of Canyamel, the persistence of $P$. nodosus is questionable due to severe human disturbances.

The only currently known population of $P$. nodosus is found near the potato production area of Sa Pobla. The crops are heavily fertilized and the probability of eutrophication is high, although $P$. nodosus seems to be tolerant to water eutrophication (Pot, 1996; Ceschin et al., 2010). The IUCN (2001) category assigned to this species by Sáez and Rosselló (2001) (near threatened, NT) is clearly inadequate. In our opinion this species can be assigned to the category of VU D2 (IUCN, 2012).

\section{References and revised specimens}

MallorCa: Font de Son Sant Joan, Muro, 20-V-1971, Bonafè (HJBS- Bonafè-0120); Font de Sant Joan, Sa Pobla, 12-VII-2005, JR-CF (UIB 16668). 


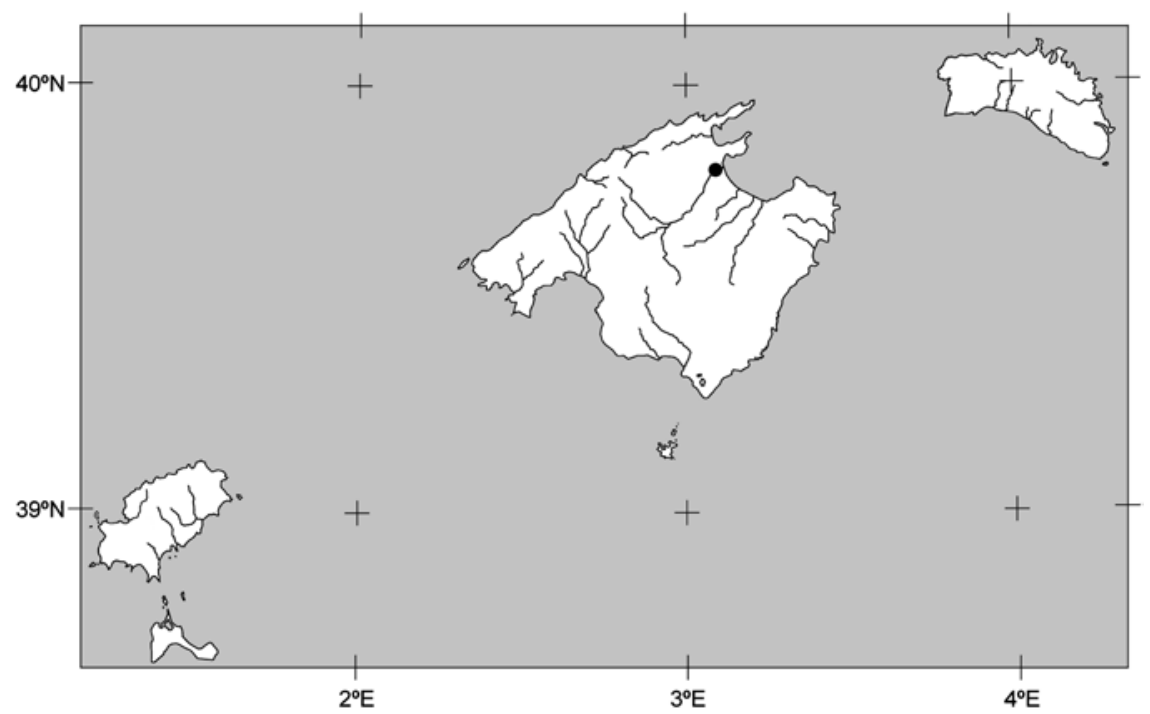

Figure 4. Distribution of Potamogeton nodosus in the Balearic Islands.

\section{Potamogeton pusillus L.}

This is a rare species in the Balearic archipelago that is restricted to a single locality in northern Mallorca (S'Albufera) and some scattered sites in southern Menorca (Rodríguez, 1874; Cardona \& Rita, 1982) (Fig. 5). It usually grows in streams and ditches. In some localities, however, $P$. pusillus are able to grow in slightly brackish conditions.

All the revised specimens present connate stipules (tubular for most of their length, at least when young, but splitting with age), axillary turions and midvein distinctly thickened towards leaf base. These characters exclude the presence of Potamogeton berchtoldii Fieber, a morphologically similar species included within the $P$. pusillus aggregate.

\section{References and revised specimens}

MALlorCA: S'Albufera, a la part alta, a les síquies dels conreus (Martínez Taberner, 1986); Pont de Son Carbonell (Martínez Taberner, 1986); Menorca: Son Bou, 11-VII-1977, s.r. (UIB 11000); Talis, Prat de Ses Canassies, 31SEE9018, 22-VII-2002, P. Fraga; Es Molí de Dalt, Barranc d'Algendar, 31SEE8225, 13 VIII-1996, P. Fraga; Prat de Bellavista, 31SEE7620, 21-VII-1998, P. Fraga.

Potamogeton schweinfurthii A. Benn.

This species, which belongs to the Potamogeton lucens group, has usually been confused with $P$. lucens, the most similar species of the genus in the Old World 


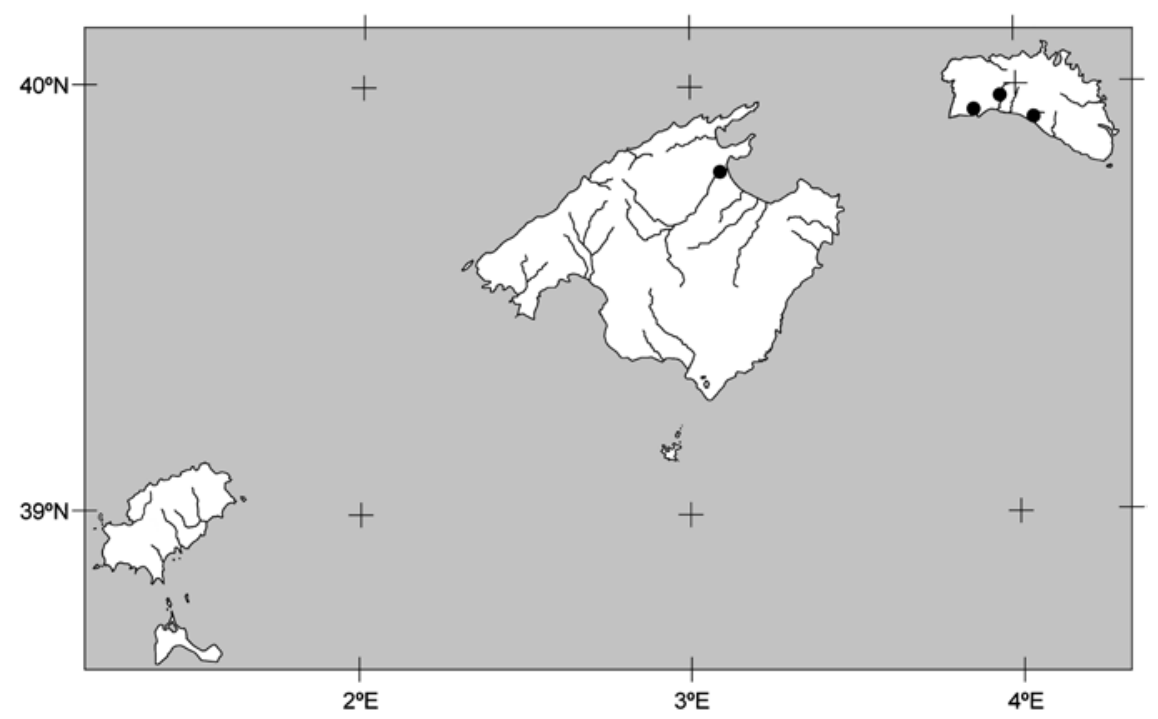

Figure 5. Distribution of Potamogeton pusillus in the Balearic Islands.

(Kaplan, 2005; Aymerich et al., 2012). Potamogeton schweinfurthii has leaves with narrowly lanceolate to narrowly elliptical laminas, mostly being 4-17 times as long as wide (2-6 times as long as wide in P. lucens). The leaves are often sessile but sometimes the upper leaves (less often all leaves) have short petioles, generally up to 5(15) $\mathrm{mm}$ long, and tend to be longer at the spike than at the base of the stem, whereas in $P$. lucens the petioles are almost always 2-7(18) $\mathrm{mm}$ long, with this length being almost the same along the stem.

Herbarium investigations confirmed the presence of $P$. schweinfurthii as a new species for the Balearic Islands. All the herbarium specimens of $P$. schweinfurthii were initially identified as $P$. lucens. Currently, these two species are commonly confused in Europe (Kaplan, 2005; Lastrucci et al., 2010; Aymerich et al., 2012). The presence of $P$. schweinfurthii - a species with wide distribution in Africa (see Kaplan, 2005) - in the Balearic Islands is not surprising, after its discovery on the islands of Corsica and Sardinia and the Iberian Peninsula (Kaplan, 2005; Lastrucci et al., 2010; Aymerich et al., 2012).

In the Balearic Islands, the presence of $P$. schweinfurthii has been confirmed for two localities: Sant Antoni de Portmany (Eivissa) and Mongofre Vell, Maó (Menorca). Habitat disturbance due to human activities has led to the disappearance of the population from Sant Antoni de Portmany. Therefore, only one population of $P$. schweinfurthii persists in the Balearic archipelago. In our opinion, this species can be assigned to the IUCN (2012) category of CR B1abiii+2abiii, D. 


\section{Revised specimens}

EIvissa: Sant Antoni de Portmany, safareig de s'Amarador, Buscastell, 31SCD5820, 5-VI-1999, N. Torres (Herb. N. Torres, sub P. lucens L.); Es Brolls, safareig quasi buit, [31S]CD5820, 6-VI-2000, L. Gil \& L. Llorens (UIB, sub P. lucens L.). MenorCa: Mongofre Vell, X 442670, Y 604030, O. García, 20-VII-2004, (Herb. Generale Minoricae sub P. lucens L.).

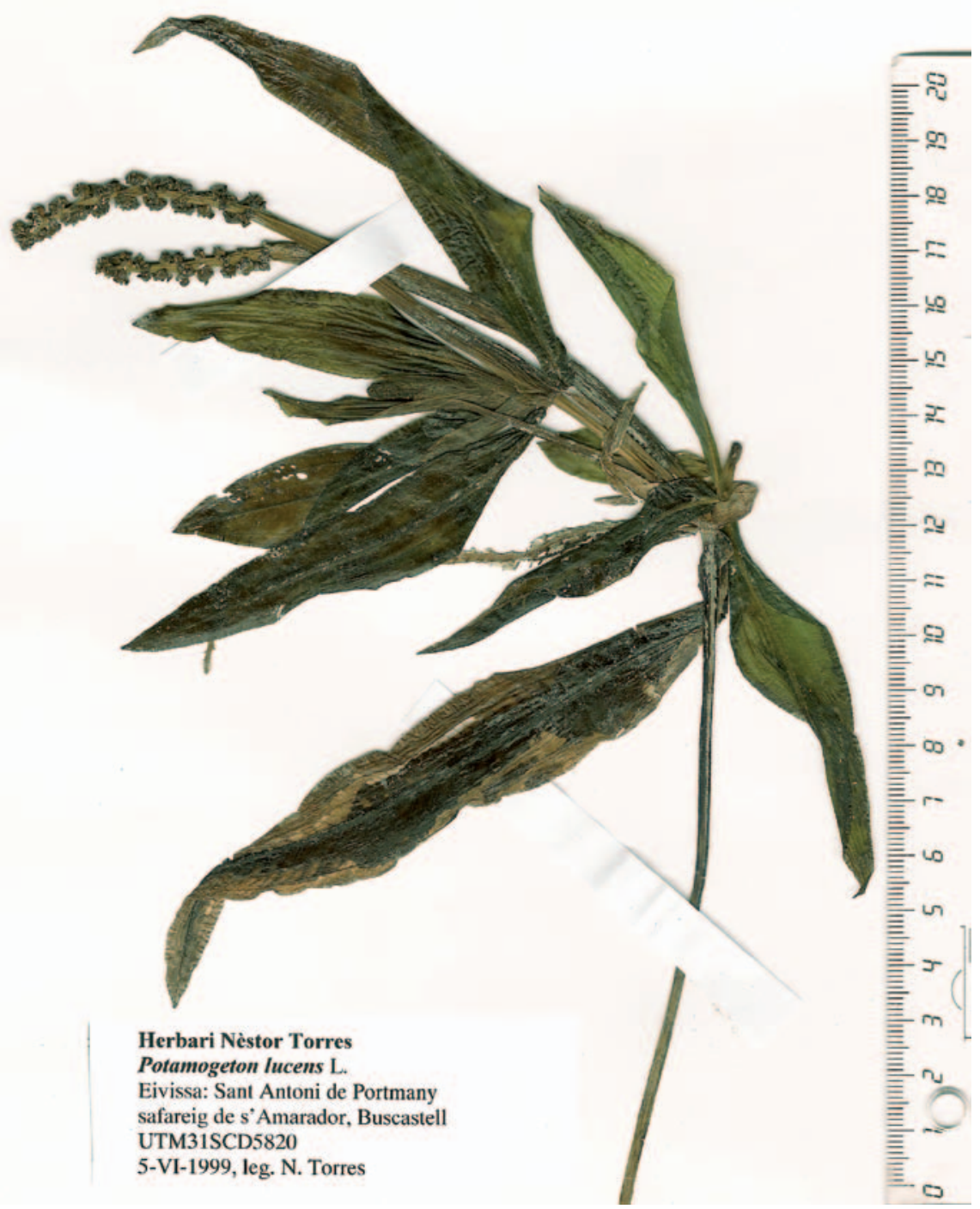

Figure 6. Specimen of Potamogeton schweinfurthii from Sant Antoni de Portmany, Eivissa. Herb. N. Torres (previously labeled as P. lucens). 


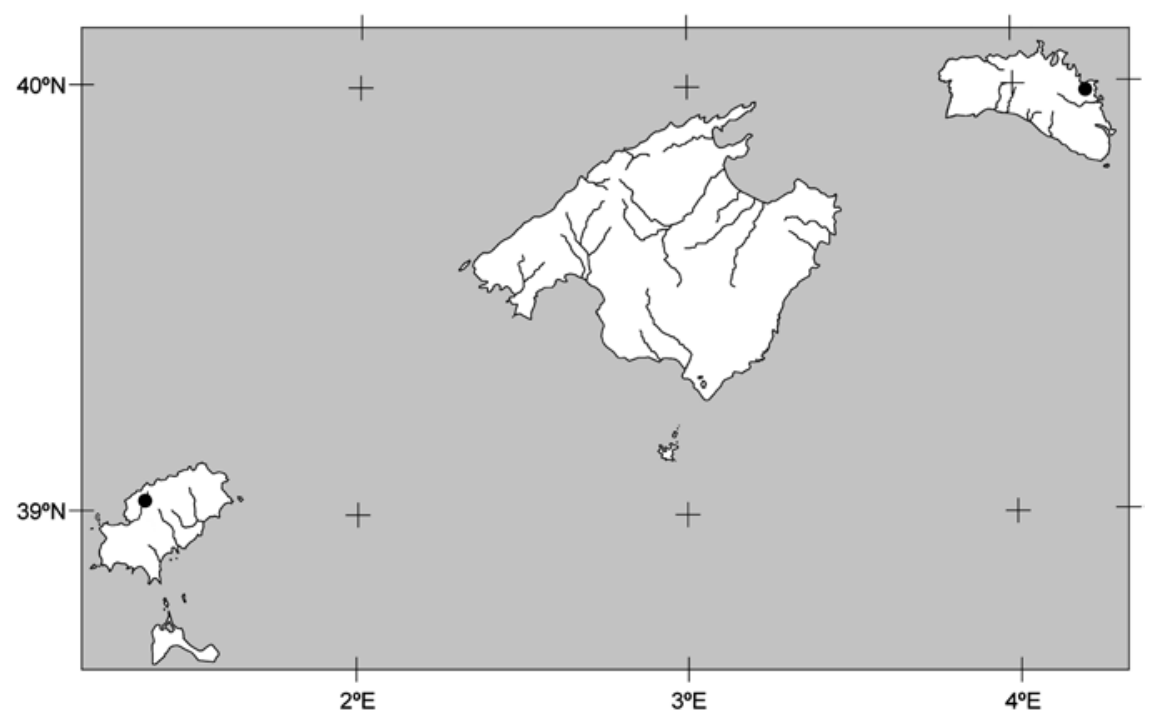

Figure 7. Distribution of Potamogeton schweinfurthii in the Balearic Islands.

\section{Stuckenia pectinata (L.) Börner}

Potamogeton pectinatus $\mathrm{L}$.

In the Balearic archipelago, this species can be found in a remarkable variety of aquatic habitats such as slow-moving water, streams, ditches, ponds, semi-permanent flooded areas and even brackish, or slightly saline coastal lagoons. Its populations can be found from sea level to almost $700 \mathrm{~m}$ above sea level. Stuckenia pectinata was reported from Cabrera without a precise locality by Bonafè (1977, sub Potamogeton pectinatus L.). This report has never been confirmed, and there is no supporting evidence that $S$. pectinata exists in Cabrera.

The Balearic specimens exhibit remarkable morphological variability, which does not appear to correlate with any infraspecific taxonomic rank, as several authors have suggested (García Murillo, 2010). In fact, not even the alleged main patterns of variability of vegetative characteristics and number of flowers attributed to certain varieties have a clear correspondence with the studied specimens. For example, there are larger plants from S'Albufera (north-eastern Mallorca) with stems often exceeding $1 \mathrm{~m}$ in length and leaf up to $3 \mathrm{~mm}$ width, which are characters of var. dichotomus Wallr. However, these plants have morphological traits of var. pectinatus: leaves with 1(3) nerves, a distinctly longer limb than the sheath, stem measuring 0.4-0.8(1) $\mathrm{mm}$ in diameter, and inflorescences rarely having more than 9 flowers. Nonetheless, most specimens are small or medium-sized plants, with stems less than $1 \mathrm{~m}$ in length, leaves up to $0.4(0.8) \mathrm{mm}$ in width, and inflorescences with 4-8 flowers, characters that do not allow a precise infraspecific category assignment (García Murillo, 2010). 


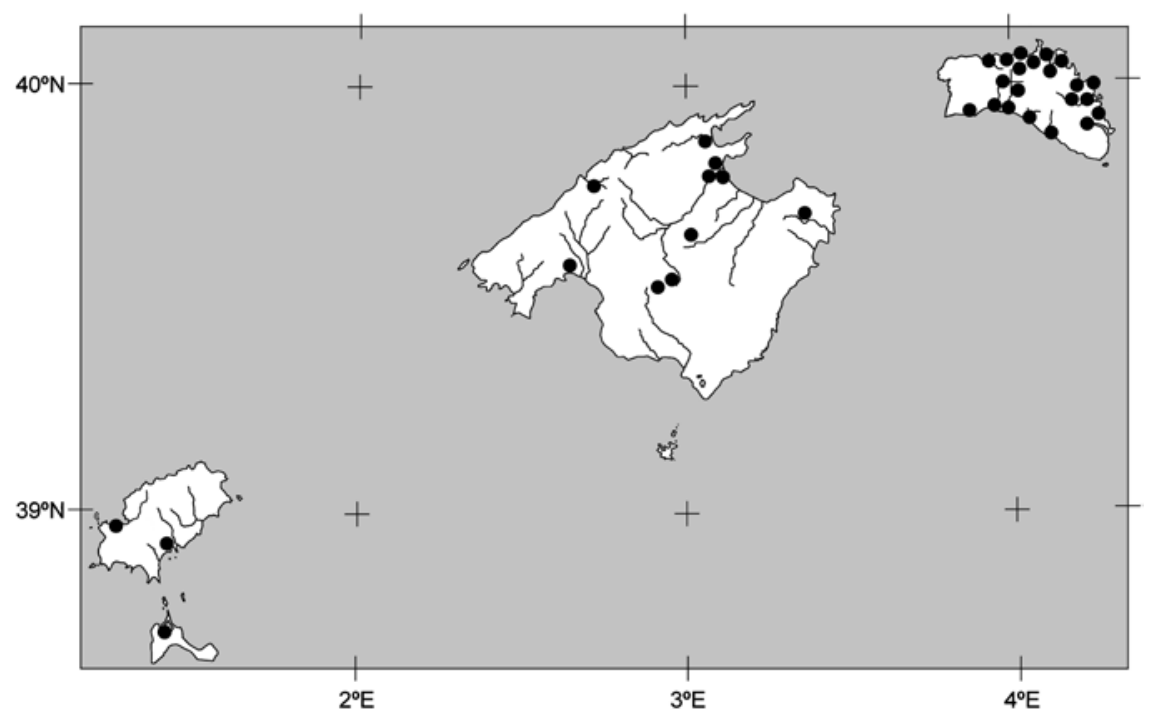

Figure 8. Distribution of Stuckenia pectinata in the Balearic Islands.

Although Stuckenia pectinata cannot be considered to be threatened in the whole of the Balearic Islands, there is strong evidence that this species has declined in sites of the Western Balearic Islands (Eivissa and Formentera) where it was formerly common over the least 20 or 30 years, and it remains absent from large stretches of apparently suitable habitat where it was once known, on the basis of herbarium specimens. In Eivissa, these coastal lagoons are often severely threatened by anthropogenic activities such as direct destruction from urban development.

\section{References and revised specimens}

MallorcA: Palma, Baleares, 1907, Mas Guindal (MA 3367); Artà, V-1934, Garcias Font (HJBS- Bonafè-0110); alrededores de Palma, aguas estancadas y balsas de riego, 15-VIII-1949, Palau Ferrer 281 (BC 112853, BCN 3310, MA 160816, MA 348159); Artà, V-1959, s.r. (HJBS- Bonafè-0112); Sóller, safareig de's camp d'en Prom, s.d., [Bonafè] (HJBS- Bonafè-0111); Albufera d'Alcúdia, 31SEE00, aigua salobre, 30-V-1985, Ll. Llorens (LLGLGV002579); Estany de ses mines de Sineu, 31SED0389, V-1988, Ll. Llorens, J.L. Gradaille \& B. Sastre (LLGLGV002580); Canal near casa at sa Roca [S'Albufera], 18-IV-1990, J.P. Newbould (Herb. Parc Natural Albufera); Albufera de Muro, 7-V-2004, J. Rita (UIB 16552); carretera Randa-Montuiri, km 5, 31SDD9677, 16-V-2004, L. Gil (LLGLGV004230); safareig de Can Rectoria (Algaida) 31SDD9175, 17-VI-2004, L. Gil (LLGLGV004234). Menorca: Turmadares (cf.) Alayor, 20-V-1873, Rodríguez (COI-Willkomm); Albufera des Grao, 10-V-1977, s.r. (UIB 11001); cruce Sa Mesquida-Es Murtar, 20-VI-1986; s.r. (UIB 15159); Prat de Bellavista, Ciutadella de Menorca, 31SEE766204, aguas de curso lento, 12-VI-1999, P. Fraga 103 
(MA 738083); Cala Pudent, s'Albufera des Comte, La Mola de Fornells, 31TEE9833, 10-V-1998, P. Fraga; Albufera des Mercadal, Son Saura, 31TEE9831, 10-V-1998, P. Fraga; Albufera des Grau, 31SFE0642, 20-VII-1997, P. Fraga; Platja des Bot, 31TEE7933, 24-V-1997, P. Fraga; Prat de Bellavista, 31SEE7620, 21-VII-1998, P. Fraga; Trebalúger, 31SEE8420, 10-VII-1996, P. Fraga; Tirant, 31TEE9433, EE9432, 28-V-2000, P. Fraga; Hort de Binissaid, Barranc d'Algendar, 31SEE8221, 7-V-1999, P. Fraga; Son Bou, prat de Ses Canssies, 31SEE9117, 22-VII-2002, P. Fraga; Cala en Porter, 31SEE9614, 2-VII-2001, P. Fraga; Barranc de Sant Joan, 31SFE0717, 21-V-2001, P. Fraga; Binillauti, 31SFE0920, 30-V-1999, P. Fraga; Santa Mariana, Favàritx, 31SFE0422, 24-V-2006, P. Fraga; Llacuna de Morella, 31SFE0706, 10-VI-2002, P. Fraga; Tordonell, 31TFE0424, P. Fraga; Es Tres Jurats, 31SFE0321, 18-VII-2007, P. Fraga; Ses Penyes, 31SFE0222, 11-VI-2006, P. Fraga; Es Clot des Guix, 31SFE0124, P. Fraga; Mongofre Vell, 31TFE0427, P. Fraga; Mongofre Nou, 31SFE0327, P. Fraga; Salines de la Concepció, 31TEE9530, Son Rubí, 31TEE873, P. Fraga; Salairó, 31TEE8933, 1-VI-1996, P. Fraga; Els Alocs, 31TEE8433, 20-VI-2011, P. Fraga; Es Pla Erm, 31SEE8427, 18-VII-2007, P. Fraga; Sa Mola, barranc de Trebalúger, 31SEE8725, 5-VI-1996, P. Fraga; Biniatzem, 31SEE8924, 20-V-1997, P. Fraga; Baix des Guix, Fornells, 31TEE9534, 20-V-1999, P. Fraga; Estància Magister, 31TEE9232, 26-V-1999, P. Fraga; Cala Barril, 31TEE8735, 15-V-2006, P. Fraga. EIVISSA: Pla de Vila, 30-VI-1920, Gros (BC 632292); Eivissa, Les Feixes, badia, 31-V-1950, R. Margalef (BC 111028), Estanque del Puerto del Torrente, San Antonio, 18-V1950, P. Ferrer (MA 145175); Sant Antoni, cala del Torrent, s.d., Palau Ferrer (BC 145630); Formentera: Es Brolls, L. Llorens (com. pers.).

\section{Excluded species}

\section{Potamogeton lucens L.}

This species was reported from Mallorca (Barceló; 1867; 1879-1881; Bonafè, 1977), Eivissa (Stafforini et al., 2001) and Menorca (Fraga \& Garcia, 2004). Records from Eivissa and Menorca (the latter assigned to P. lucens by García Muri1lo, 2010) are in fact referable to $P$. schweinfurthii (see comments under this species), while the validity of the Majorcan reports are discussed here.

Barceló (1879-1881) indicated P. lucens from "acequia de la Bastera, Palma, raro" [an irrigation ditch near Palma, Mallorca]. We have not found any herbarium specimen that confirms the presence of P. lucens in this locality nor in any other area of the Balearic Islands. We also tried to locate this species in the locality of "sa Bastera", but currently there is virtually no hygrophilous vegetation, and we have therefore been unable to locate any species of the genus Potamogeton.

The report of $P$. lucens from Serra de Tramuntana (Bonafè, 1977) is supported by several herbarium specimens (Mallorca: Gorg Blau, VIII-1968, Bonafè, HJBSBonafè-0124 and HJBS-Bonafè-0127) currently preserved in the herbarium of the Sóller Botanical Garden. On the basis of this report, the presence of P. lucens in the Balearic Islands is currently accepted (Pla et al., 1992), and it is listed in com- 
pilations on threatened flora of the archipelago (Sáez \& Rosselló, 2001), where it appears as "Endangered" (EN) according to IUCN (2001) criteria.

The study of herbarium material labelled as P. lucens from Gorg Blau suggests that this may not correspond to this species, since the specimens have petioles highly irregular in length (in $P$. lucens this length is fairly constant), some of which are very long $(4-5 \mathrm{~cm})$ (whereas in $P$. lucens they measure c. $1 \mathrm{~cm}$ ). Furthermore, the following characters rule out the possibility that this herbarium material may be referable to $P$. schweinfurthii (a species which has sometimes been confused). The specimens have no sessile or subsessile submerged leaves, nor are the peduncles clearly thickened and wider than the corresponding spike, as is characteristic of $P$. schweinfurthii. The size of the spike or of the fruit (less than $2 \mathrm{~mm}$ ) are not referable to the latter species either. On the other hand, specimens HJBS 124 and HJBS 127 fall into the variability of $P$. coloratus on the basis of fruit size and by the presence of very long stalks ( $P$. coloratus is the species with longer pedicels). In these specimens, some stalks show a weak thickening. This character, although not specified in the literature, has been observed in some north-eastern Iberian populations of $P$. coloratus. Regarding leaf characters, Majorcan specimens may have few leaf veins, but as discussed previously, this character can be variable according to the location of the leaves and their size.

Finally, there is additional evidence suggesting that plants collected by F. Bonafè in Gorg Blau and labelled as P. lucens correspond to P. coloratus: i) under the same set of specimens (correlatively numbered) there are specimens labelled as $P$. coloratus by F. Bonafè. The morphology of these specimens is almost identical to the plants identified as $P$. lucens, and ii) the same F. Bonafè initially identified the specimens HJBS 124 and 127 as P. coloratus. It is therefore obvious that he was hesitant about the identity of these plants.

Therefore, we can conclude that samples from Gorg Blau hitherto referred to as $P$. lucens must be ascribed to $P$. coloratus, and that in the absence of voucher specimens and reliable references of $P$. lucens, this species should be excluded from the flora of the Balearic Islands.

\section{Potamogeton natans L.}

This species was reported from Mallorca (“acequias de Artá”) and Eivissa (without precise locality) by Cambessèdes (1827) and Barceló (1879-1881), respectively. Later, this information was repeated by several authors (Bonafè, 1977; Smythies, 1986; Rivas-Martínez et al., 1992; Pla et al., 1992; Bolòs \& Vigo 2001).

Knoche (1921) was the first author to ascribe the reports of $P$. natans due to Cambessèdes (1827) and Barceló (1879-1881) to P. coloratus. However, P. natans has subsequently been considered as possibly present in the Balearic archipelago (Bonafè, 1977; Pla et al., 1992).

The voucher specimen that served as a basis for the report of $P$. natans from Mallorca [Arta, 15-IV-1825 [Cambessèdes] (MPU-Knoche)] belongs to P. coloratus. In addition, some herbarium specimens labelled as $P$. natans and collected by F. Bonafè in Artà (HJBS-Bonafè-0122 and HJBS- Bonafè-0126) and Lluc 
(HJBS- Bonafè-0123) are also referable to $P$. coloratus. We have tried to find Eivissan material of $P$. natans in several herbaria without success, and do not believe that this plant is found in Eivissa. Therefore this species must be excluded from the flora of the archipelago.

\section{Acknowledgements}

We would like to thank the curators of all the herbaria visited. We thank the editor and two anonymous reviewers for their constructive comments, which helped us to improve the manuscript.

\section{Bibliographical references}

Aymerich, P.; Kaplan, Z.; Guardiola, M.; Petit, A.; Schwarzer, U. 2012. Potamogeton schweinfurthii in the Iberian Peninsula. Anales Jard. Bot. Madrid 69(2): 187-192.

Barceló, F. 1867. Apuntes para una Flora de las islas Baleares [Part. 2]. [Real Academia de Ciencias exactas, físicas y naturales] Madrid.

Barceló, F. 1879-1881. Flora de las Islas Baleares, seguida de un diccionario de los nombres baleares, castellanos y botánicos de las plantas espontáneas y cultivadas. Imp. P.J. Gelabert. Palma de Mallorca.

Bolòs, O.; Vigo, J. 2001. Flora dels Països Catalans Vol. 4. Ed. Barcino. Barcelona.

Bonafè, F. 1977. Flora de Mallorca. Vol. 1. Ed. Moll. Palma de Mallorca.

Brochet, A.L.; Guillemain, M.; Fritz, H.; Gauthier-Clerc, M.; Green, A.J. 2010. Plant dispersal by teal (Anas crecca) in the Camargue: duck guts are more important than their feet. Freshwater Biology 55: 1262-1273.

Cambessèdes, J. 1827. Enumeratio Plantarum quas in insulis Balearibus collegit. Mém. Mus. Hist. Nat. 14: 173-335.

Cardona, M.A.; Rita, J. 1982. Aportació al coneixement de la flora balear. Folia Bot. Misc. 3: $35-42$.

Ceschin, S.; Zuccarello, V.; Caneva, G. 2010. Role of macrophyte communities as bioindicators of water quality: Application on the Tiber River basin (Italy). Pl. Biosystems 144: 528-536.

Fraga, P.; Garcia, O. 2004. Notes i contribucions al coneixement de la flora de Menorca (VI). Boll. Soc. Hist. Nat. Balears 47: 143-152.

García Murillo, P. 2010. Potamogeton L. In: Talavera, S.; Gallego, M.J.; Romero Zarco, C. \& Herrero, A. (eds.). Flora iberica. Vol. XVII. Butomaceae-Juncaceae. Real Jardín Botánico-CSIC. Madrid. p. 64-85.

IUCN. 2001. IUCN Red List Categories and Criteria: Version 3.1. Gland, Switzerland and Cambridge, UK.

IUCN. 2012. IUCN Red List Categories and Criteria: Version 3.1. Second edition. Gland, Switzerland and Cambridge, UK.

Kaplan, Z. 2002. Phenotypic plasticity in Potamogeton (Potamogetonaceae). Folia Geobot. 37: 141-170.

Kaplan, Z. 2005. Potamogeton schweinfurthii A. Benn., a new species for Europe. Preslia 77: 419-431.

Kaplan, Z. 2008. A taxonomic revision of Stuckenia (Potamogetonaceae) in Asia, with notes on the diversity and variation of the genus on a worldwide scale. Folia Geobot. 43: $159-234$. 
Knoche, H. 1921. Flora Balearica. Etude phytogéographique sur les îles Baléares. Vol. 1. Imp. Roumégous et Déhen, Montpellier.

Koch, E.W.; Ailstock, M.S.; Booth, D.M.; Shafer, D.J.; Magoun, A.D. 2010. The Role of Currents and Waves in the Dispersal of Submersed Angiosperm Seeds and Seedlings. Restoration Ecology 18: 584-595.

Lastrucci, L., Frignani, F.; Kaplan, Z. 2010. Potamogeton schweinfurthii and similar broad-leaved species in Italy. Webbia 65(1): 147-160.

Llorens, L. 1972. Anotaciones a la flora balear. Bol. Soc. Hist. Nat. Baleares 17: 56-62.

Martínez Taberner, A. 1986. Notes florístiques: faneròfits aquàtics de s'Albufera de Mallorca. Boll. Soc. Hist. Nat. Balears 30: 155-164.

Pla, V.; Sastre, B.; Llorens, L. 1992. Aproximació al catàleg de la flora vascular de les Illes Balears. Universitat de les Illes Balears, Jardí Botànic de Sóller. Palma.

Pot, R. 1996. A reference system for continental running waters: plant communities as bioindicators of increasing eutrophication in alkaline and acidic waters in norheast France. In Caffrey, J.M.; Barrett, P.R.F.;Murphy, K.J.; Wade, P.M. (eds.). Management and Ecology of Freshwater Plants: 67-76. Kluwer Academic Press.

Rivas-Martínez, S.; Costa, M.; Loidi, J. 1992. La vegetación de las islas de Ibiza y Formentera (Islas Baleares, España). Itinera Geobot. 6: 99-236.

Rodríguez, J.J. 1874. Suplemento al catálogo de plantas vasculares de Menorca. Anales Soc. Esp. Hist. Nat. 3(1): 5-68.

Rodriguez, J.J. 1904. Flórula de Menorca. Impr. Fàbregues, Maó.

Sáez, L.; Rosselló, J.A. 2001. Llibre Vermell de la flora amenaçada de les Illes Balears. Conselleria de Medi Ambient. Govern de les Illes Balears. Palma de Mallorca.

Smythies, B.E. 1986. Flora of Spain and the Balearic Islands. Checklist of vascular Plants, III. Salicaceae-Zygophyllaceae, Agavaceae-Zannichelliaceae. Englera 3(2): 213-486.

Stafforini, M.; Torres, N.; Sáez, L.; González, J.M.; Duñó, J.; Puget, G. 2001. Notes florístiques de les Illes Balears. Boll. Soc. Hist. Nat. Balears 44: 57-66.

Wiegleb, C.; Kaplan, Z. 1998. An account of the species of Potamogeton L. Folia Geobot. 33: 241-316.

Zhang, X.L.; Gituru, R.W.; Yang, C.F.; Guo, Y.H. 2010. Exposure to water increased pollen longevity of pondweed (Potamogeton spp.) indicates different mechanisms ensuring pollination success of angiosperms in aquatic habitat. Evolutionary Ecology 24: 939-953. 